\title{
POST-PRUNING GROWTH OF SOME AFFORESTATION SPECIES IN THE METROPOLITAN REGION OF BELO HORIZONTE, MINAS GERAIS STATE, BRAZIL
}

\author{
Rafael Malfitano Braga $2^{2 *}$,Marina Moura de Souza $^{3} \odot$, Francisco de Assis Braga ${ }^{4}$ and Nelson Venturin ${ }^{2}$, $^{\circ}$
}

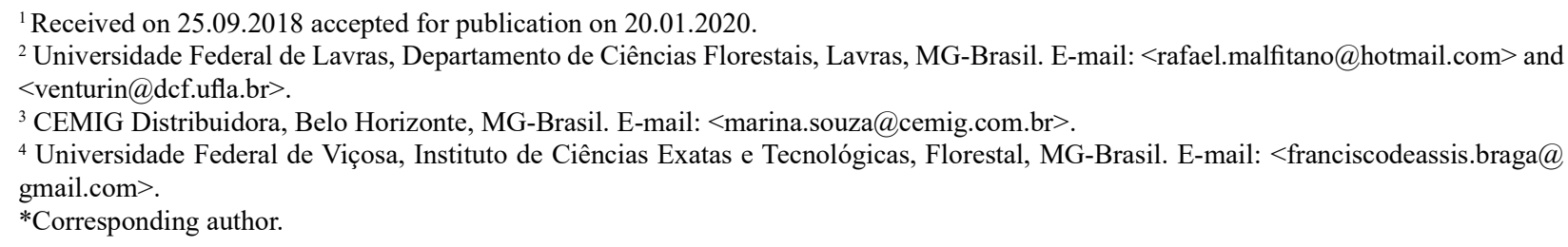

ABSTRACT - The post-pruning growth of the 16 main species planted in urban afforestation in the Metropolitan Region of Belo Horizonte was evaluated in order to adjust the pruning regime, as well as to evaluate the effect of environmental, management, and tree factors on shoot development. Six individuals were selected per species, and the monthly growth of the five largest shoots at the pruned points was monitored to create two scenarios, considering the median and third quartile of the growth data. The grouping analysis of the growth data was carried out, defining groups of pruning regime according to the similarity in the species growth. Correlation and linear regression analyses were also performed for climatic factors, pruning intensity, diameter at breast height (DBH), phytosanitary status, luminosity in the crown, and permeable area in the soil. It was verified that the arboreal species studied presented a differentiated growth response of post-pruning shoots and can be combined into groups of pruning management regimes ranging from 6 to 24 months. Environmental, individual, and management factors can affect tree sprouting.

Keywords: Urban afforestation, Urban tree management, Urban tree sprouting.

\section{CRESCIMENTO PÓS-PODA DE ALGUMAS ESPÉCIES DA ARBORIZAÇÃO NA REGIÃO METROPOLITANA DE BELO HORIZONTE, MINAS GERAIS, BRASIL}

\begin{abstract}
RESUMO - Avaliou-se o crescimento pós-poda das 16 principais espécies plantadas em arborização urbana na Região Metropolitana de Belo Horizonte com objetivo de adequar o regime de podas e avaliar o efeito de fatores ambientais, de manejo e da árvore no desenvolvimento das brotações. Foram selecionados seis indivíduos por espécie e acompanhado o crescimento mensal das cinco maiores brotações nos pontos podados, criando-se dois cenários, considerando os valores da mediana e do terceiro quartil dos dados de crescimento. Procedeuse a análise de agrupamento dos dados de crescimento, definindo-se grupos de regime de poda de acordo com a similaridade de hábito de crescimento das espécies. Realizou-se também análises de correlação e regressão linear para fatores climáticos, intensidade de poda, diâmetro a altura do peito, estado fitossanitário, intensidade de luz na copa e área permeável no solo. Constatou-se que as espécies arbóreas estudadas apresentam resposta diferenciada de crescimento das brotações pós-poda, podendo ser reunidas em grupos de regimes de manejo de podas, variando entre 6 e 24 meses. Fatores ambientais, do indivíduo arbóreo e de manejo podem afetar o desenvolvimento da brotação das árvores.
\end{abstract}

Palavras-Chave: Arborização urbana, Manejo de árvores urbanas, Condução da brotação de árvores urbanas.

Silf $(c)) \mathrm{EY}$

Revista Árvore 2020;44:e4411

http://dx.doi.org/10.1590/1806-908820200000011 


\section{INTRODUCTION}

The model of urbanization can directly affect people's quality of life (Cabral, 2013; Salbitano et al., 2016), making it essential to search for alternatives to match population growth and environmental quality (Fontoura, 2011; Miller et al., 2015). In this context, afforestation in cities fulfills a relevant role in terms of aesthetics, landscape, comfort, and ambience (GómezBaggethun and Barton, 2013).

Urban tree-planting is an onerous activity and requires planning and technical consideration (Sagebiel et al., 2017). Performed correctly, it minimizes the need for future interventions and risks of conflicts between trees and other urban structures (Melo and Severo, 2010).

Among the urban structures, the electricity distribution network and public lighting show greater interaction potential with afforestation (CEMIG, 2011). Therefore, the planning and adaptation of the methods and maintenance systems of the afforestation promote security for the electrical system and the infrastructure of the city (Miller et al., 2015).

The present work proposes to evaluate the post pruning growth of the main species used in urban afforestation. This was done in order to adapt the pruning regime and to identify the main determinants of tree development, as well as to improve the relationship between urban trees and city infrastructure.

\section{MATERIAL AND METHODS}

The work was developed in the metropolitan region of Belo Horizonte (RMBH) with an area of $331 \mathrm{~km}^{2}$. Belo Horizonte city is one of the most forested capitals in Brazil, having around 600 thousand urban trees and more than 200 species cataloged. This maintains a value above the minimum of 10 to $12 \mathrm{~m}^{2}$ per inhabitant, recommended by the World Health Organization (Gomes, 2005).

The species were chosen from the database of Energy Company of Minas Gerais (CEMIG), which records the demand for pruning and frequency of interruptions associated with trees and the electric power grids at RMBH. The report until the year 2016 identified 16 "problem species", which represent about $60 \%$ of the number of individuals planted in the afforestation of the capital of the state of Minas Gerais.
These that were more critical for monitoring and management include: Munguba (Pachira Aquatica Aubl.), Espatódea (Spathodea campanulata P. Beauv.), Oiti (Licania tomentosa (Benth.) Fritsch.), Magnólia (Magnolia champaca (L.) Baill. ex Pierre.), Mangueira (Mangifera indica L.), Sibipiruna (Caesalpinia pluviosa var. peltophoroides (Benth.) G. P. Lewis.), Quaresmeira (Tibouchina granulosa (Desr.) Cong.), JacarandáMimoso (Jacaranda mimosaefolia D. Don.), EscumilhaAfricana (Lagerstroemia speciosa (L.) Pers.), Fícus-Benjamim (Ficus benjamina L.), Ipê-Rosado (Handroantus pentaphylla (L.) Mattos.), Bauhinia (Bauhinia forficata Link), Alfeneiro (Ligustrum lucidum Ait.), Flamboyant (Delonix regia (Bojerex Hook.) Raf.), Paineira (Ceiba speciosa (A. St.-Hil.) Ravenna.), and Castanheira (Terminalia catappa L.).

After this identification in the database, six individuals of each of these species were identified in the urban mesh and evaluated, including one control, thus, totaling 96 trees. Phenotypically characteristic samples of each species with good development and adequate phytosanitary status were selected on RMBH streets, sampling that includes the counties of Belo Horizonte, Betim and Contagem.

In the first week of January 2014, pruning was performed with the use of a two meter radius safety area of in the vicinity of the electricity cables in the urban network, as recommended by technical standards (CEMIG, 2011). Monthly growth of shoots of five points per individual was measured monthly, using the largest sprouting of each measured point.

The monthly values of the median and third quartile shoot length were used in the definition of groups of similarity by cluster analysis to generate two scenarios of pruning regimes: liberal - using the median as reference; and conservative - using third quartile.

From the clustering analysis, the cut-off line was defined by organizing the groups of pruning regimes. From the database of the trees inventoried in Belo Horizonte, it was possible to define the percentage that each species represents of the total trees pruned by CEMIG in the RMBH in the areas of study. This percentual base was used to quantify the potential management of each pruning group and to estimate the service demand in each scenario.

The effect of environmental conditions, tree characteristics, and pruning intensity on shoot growth

Revista Árvore 2020;44:e4411 
was evaluated, considering the following points: pruning intensity (light pruning, less than $10 \%$ of crown volume; moderate pruning, between $10-30 \%$; and heavy pruning, over 30\%); circumference at the level of the chest (CAP); mean annual rainfall and temperature (1990 to 2015 - INMET historical series about monthly average temperature and rainfall); soil permeable area (adequate, over $0.7 \mathrm{~m}^{2}$; moderate, between $0.7-0.4 \mathrm{~m}^{2}$; and restricted, less than $0.4 \mathrm{~m}^{2}$ ); crown percentage with incidence of direct sunlight with the percentage estimate of canopy area illuminated directly by midday sunlight (full light, more than $80 \%$ of canopy with incidence of direct sun light; half shadow, between $20-80 \%$; and shadow, less than $20 \%$ ); phytosanitary status, defined by presence and intensity of injuries (perfect state, no apparent injury; few injuries, injury affecting up to $15 \%$ of any part of the tree; moderate injuries, injury that compromises between 15 and $33 \%$ of any part of the tree; serious injuries, injury that compromises more than $33 \%$ of any part of the tree).

Linear regression analyses were performed between the variables of growth, temperature and rainfall. For the pruning intensity, CAP, soil permeable area, crown percentage with incidence of direct sunlight, and phytosanitary status, correlation analysis and boxplot distribution were performed to understand the relationship between the parameters.

\section{RESULTS}

\subsection{Monthly growth of shoots}

In the first month after pruning, it was observed that at least one specimen of each species emitted sprouts. In other words, only 27 of the 96 evaluated trees did not sprout. All individuals of Escumilha, Jacaranda, Magnolia, Mangueira, and Munguba sprouted in the first month, and this was the case for only one individual from Oiti and Fícus. In the second month, another 16 trees presented shoots, highlighting all individuals from Oiti. In the third and fourth measurements, eight more trees sprouted, leaving only one specimen of Castanheira, Flamboyant, and Paineira that did not emerge during the one-year follow-up period. The monthly growth of shoots per species during the year varied (Figures 01 and 02).

\subsection{Definition of pruning regimes}

The cluster analysis of sprout growth generated two scenarios - both liberal and conservative (Figure 02), which facilitated the organization of species in similarity groups of pruning regimes (Table 01).

In the first scenario (liberal), the three species included in Group A presented the highest annual growth of shoots, requiring an eight-month pruning regime. In Group B, the ideal pruning regime is twelve months, being utilized currently. The species of Group $\mathrm{C}$ can have their pruning regime extended to 16 months without prejudice to maintenance. Species with slow sprout growth, such as Ficus, can be pruned every 24 months.

In the second scenario (conservative), species of rapid sprouting (Group A), such as Pata-de-Vaca, require a more intensive, semi-annual pruning regime. For Group B, it is also recommended to increase the number of pruning operations by $30 \%$, being every eight months. Group $\mathrm{C}$ would be maintained under the current annual management regime, while in Group D, the species would have its pruning regime extended to one year and four months.

\subsection{Influence of environment, individual, and man gement conditions on shoot growth}

The linear regression model fit indicated a significant relationship between the monthly historical averages of temperature and precipitation with shoot growth (Table 02).

In terms of pruned crown percentage, correlation analysis indicated distinct species behavior relationships (Table 03), varying in intensity and effect (positive or negative). When all species were considered together, there was a low negative correlation. In other words, the volume of the crown removed was not determinant to define the size of the shoots emitted later.

The correlation between tree diameter and sprouting was quite heterogeneous. In terms of permeable soil area, there was a significant negative correlation $(-0.35)$ in the growth of shoots of all species, especially Espatódea, Castanheira, and Paineira. Regarding the health, presence, and severity of lesions in the trees sampled, as well as their influence on the shoots, there was a direct and highly significant relation $(p<0.001)$ between these factors. Finally, in relation to the solar incidence, the highest shoots were observed for those trees with direct solar incidence, regardless of the species $(\mathrm{p}<0.001)$.

\section{Revista Árvore 2020;44:e4411}




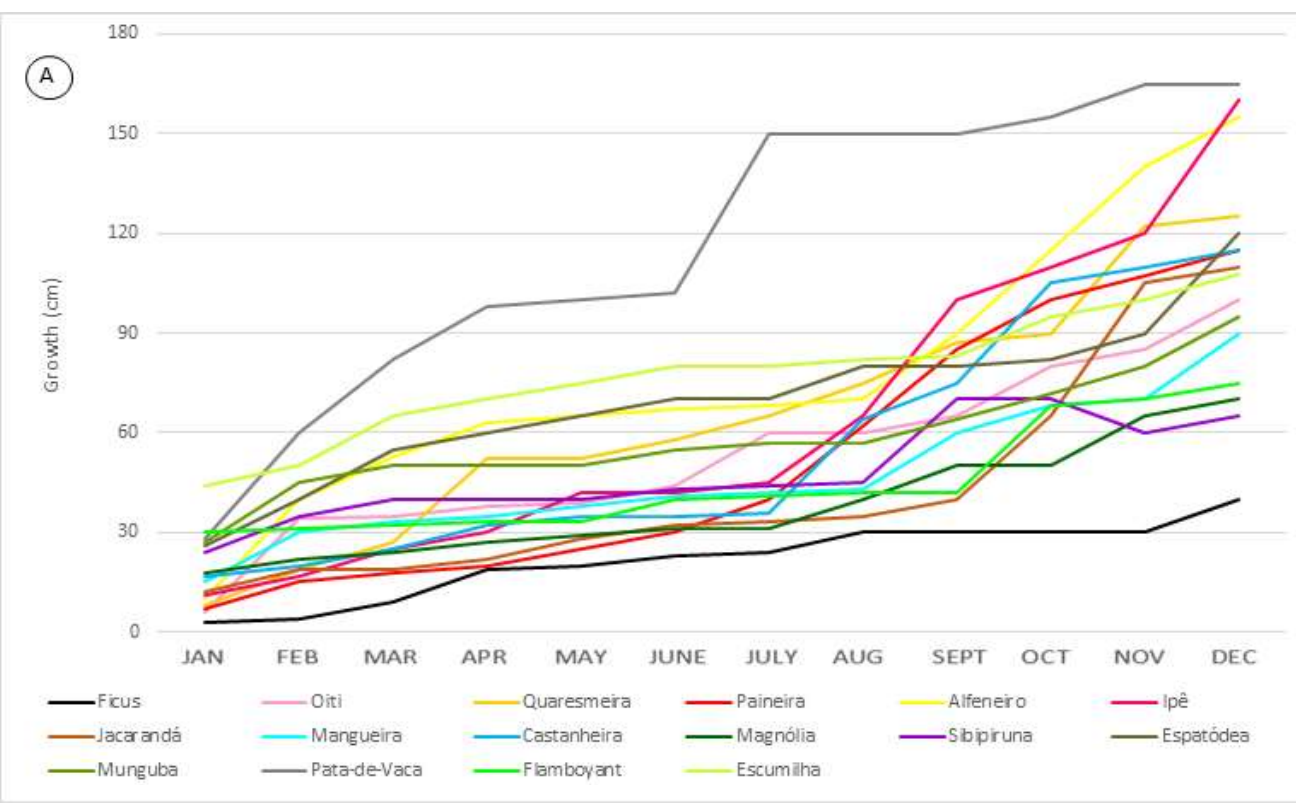

250

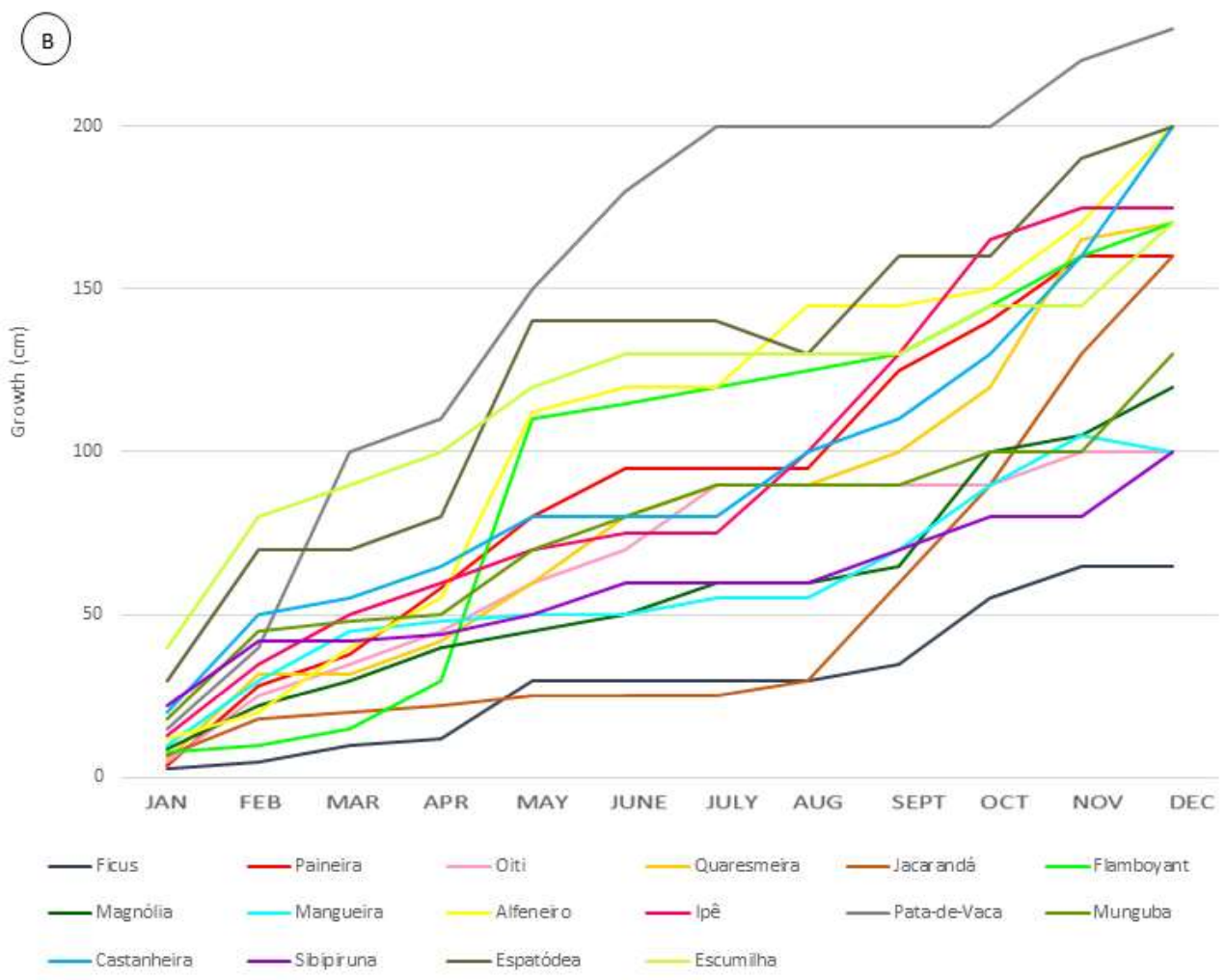

Figure 1 - Monitoring the growth of shoots by post-pruning shoots species throughout the year. Scenario A: median growth of shoots.

Scenario B: third quartile growth of shoots.
Figura 1 - Acompanhamento do crescimento das brotaços pós-poda das espécies ao longo do ano. Cenário A: mediana de crescimento das brotações. Cenário B: terceiro quartil de crescimento das brotações.

\section{Revista Árvore 2020;44:e4411}




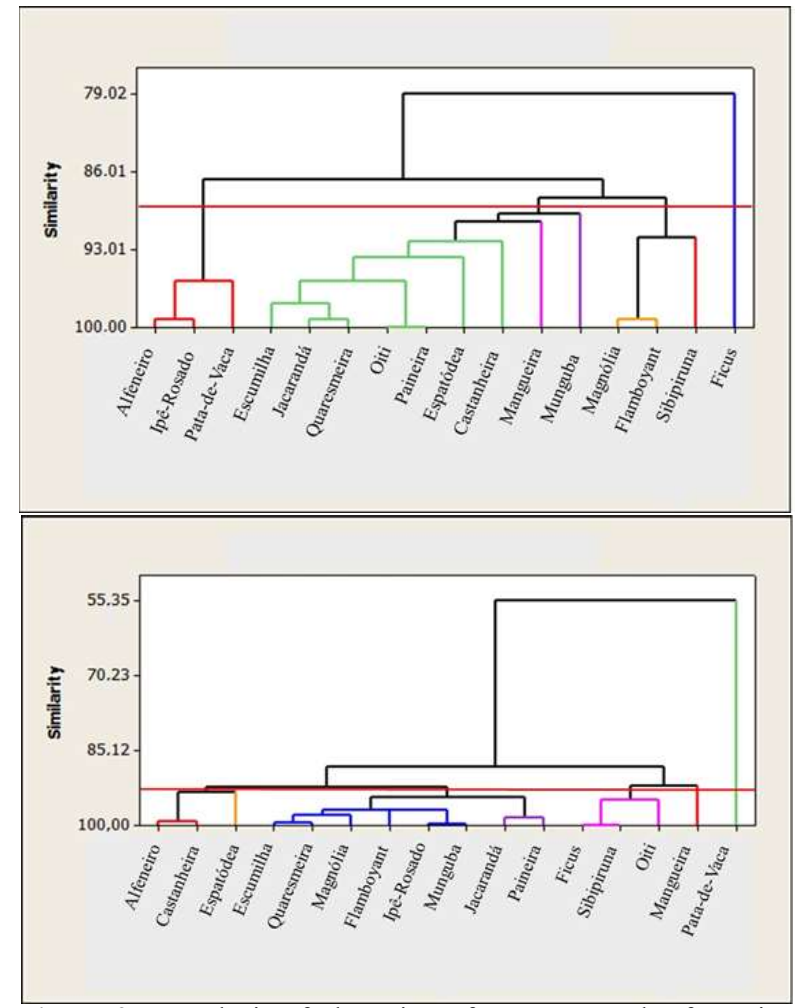

Figure 2 - Analysis of clustering of sprout growth of species. Scenario A: median growth of shoots. Scenario B: third quartile growth of shoots.

Figura 2 - Análise de agrupamento de crescimento das brotações por espécie. Cenário A: mediana de crescimento das brotações. Cenário B: terceiro quartil de crescimento das brotações.

\section{DISCUSSION}

\subsection{Monthly growth of shoots}

The sprout length of Pata-de-Vaca and little development of Fícus throughout the period are notable. It can be observed that Alfeneiro, Ipê, and Jacarandá presented a growth spurt in the spring period (beginning of rainy season), while Munguba, Mangueira, Sibipiruna, and Oiti had lower growth rates in relation to the others. The other species showed relatively continuous development and presented a reduction only in the winter period (cold and dry period), which was probably associated with the drop in the air temperature and the reduction of rainfall and solar radiation (Wang et al., 2017).

This differentiation of shoot growth rate between species indicates the need to adopt differentiated pruning regimes, reducing the possibility of conflicting interactions between afforestation and other urban structures (Blum et al., 2008; Vogt et al., 2015).

At the end of study period, it was observed that only one specimen of Castanheira, Flamboyant, and Paineira did not emerge during the one-year follow-up period. These three individuals have low pruning crown volumes and no direct sunlight in the area of pruning incisions, which may explain the lack of physiological stimulation to sprout (Taiz and Zeiger, 2006; Ferreira et al., 2019).

\subsection{Definition of pruning regimes}

Analyzing the proposals for changes to the pruning plan in the first scenario (daring), these changes would result in a new pruning regime, optimizing the results and reducing the costs and demand of interventions on the order of $3 \%$ of the annual standard for the species studied. Considering the second scenery (conservative), the suitability would result in an increase of about $2.5 \%$ of pruning of the species studied in the RMBH in order to obtain the expected results for afforestation management.

The adaptation of the pruning regimes to the growth rate of shoots of each group of species, regardless of the adoption of one or another scenario (conservative or liberal), becomes essential to ensure the most appropriate management of urban afforestation (Salbitano et al., 2016; Sagebiel et al., 2017).

\subsection{Influence of environmental, individual, and management conditions on shoot growth}

Considering all the species studied, there was a positive correlation between climatic factors and shoot development. In other owrds, with high temperatures and available precipitation, there is an increase in growth. This is a fact physiologically expected by the association between environmental conditions and plant development (Blagitz et al., 2016). However, considering the species individually, it was observed that the climatic factors affected trees differently. IpêRosado, Jacarandá-Mimoso, Paineira, and Sibipiruna presented high and positive correlation. However, for the others, this relationship was not so close. This demonstrates that the current pruning standard, which considers all common species have similar post-pruning behavior, would not be the most appropriate approach, as also suggested by Brun et al. (2007). 
Table 1 - Scenarios of sets of pruning groups. Scenarios A: median of sprout growth data. Scenarios B: third quartile of shoot growth data. Tabela 1 - Scenarios of sets of pruning groups. Scenarios A: median of sprout growth data. Scenarios B: third quartile of shoot growth data.

\begin{tabular}{|c|c|c|c|c|}
\hline \multicolumn{5}{|c|}{ Scenario A } \\
\hline Pruning Group & Species & Sprouting length $(\mathrm{cm})$ & $\%$ Pruned Trees RMBH & Total $(\%)$ \\
\hline \multirow{3}{*}{ A } & Pata-de-Vaca & \multirow{3}{*}{$>150$} & 5.8 & \multirow{3}{*}{14.6} \\
\hline & Ipê-Rosado & & 3.6 & \\
\hline & Alfeneiro & & 5.2 & \\
\hline \multirow{9}{*}{ B } & Castanheira & \multirow{9}{*}{$81-150$} & 6.6 & \multirow{9}{*}{23.7} \\
\hline & Quaresmeira & & 2.5 & \\
\hline & Paineira & & 0.9 & \\
\hline & Escumilha & & 2.9 & \\
\hline & Jacarandá & & 1.2 & \\
\hline & Espatódea & & 1.6 & \\
\hline & Oiti & & 3.1 & \\
\hline & Mangueira & & 2.3 & \\
\hline & Munguba & & 2.6 & \\
\hline \multirow{3}{*}{$\mathrm{C}$} & Flamboyant & \multirow{3}{*}{$50-80$} & 2.6 & \multirow{3}{*}{20.0} \\
\hline & Magnólia & & 1.8 & \\
\hline & Sibipiruna & & 15.6 & \\
\hline \multirow[t]{2}{*}{$\mathrm{D}$} & Fícus & $<50$ & 2.3 & 2.3 \\
\hline & & Total & & 60.6 \\
\hline \multicolumn{5}{|c|}{ Scenario B } \\
\hline Pruning Group & Species & Sprouting length $(\mathrm{cm})$ & $\%$ Pruned Trees RMBH & Total $(\%)$ \\
\hline $\mathrm{A}$ & Pata-de Vaca & $>200$ & 5.8 & 5.8 \\
\hline \multirow{3}{*}{ B } & Castanheira & \multirow{3}{*}{$181-200$} & 6.6 & \multirow[t]{3}{*}{13.4} \\
\hline & Alfeneiro & & 5.2 & \\
\hline & Espatódea & & 1.6 & \\
\hline \multirow{8}{*}{$\mathrm{C}$} & Paineira & \multirow{8}{*}{$100-180$} & 0.9 & \multirow[t]{8}{*}{18.1} \\
\hline & Jacarandá & & 1.2 & \\
\hline & Munguba & & 2.6 & \\
\hline & Ipê-Rosado & & 3.6 & \\
\hline & Flamboyant & & 2.6 & \\
\hline & Magnólia & & 1.8 & \\
\hline & Escumilha & & 2.9 & \\
\hline & Quaresmeira & & 2.5 & \\
\hline \multirow{4}{*}{$\mathrm{D}$} & Mangueira & \multirow{4}{*}{$<100$} & 2.3 & \multirow[t]{4}{*}{23.3} \\
\hline & Oiti & & 3.1 & \\
\hline & Fícus & & 2.3 & \\
\hline & Sibipiruna & & 15.6 & \\
\hline
\end{tabular}

Evaluating the behavior by species, Pata-de-Vaca, Jacarandá-Mimoso, Alfeneiro, and Espatódea presented a high positive correlation between sprout development and pruned crown volume. That is to say, in principle, the higher pruning intensity (up to $30 \%$ of the crown) for these species results in higher sprouting and possibly greater need for intervention (Bobrowski et al., 2017). However, for Mangueira, Munguba, and Paineira, there was an inverse behavior, resulting in a high negative correlation, or in other words, the greater intervention in the crown would generate greater stress in the plant, causing less vigor in shoots (Jacob Neto et al., 2016).
The correlation between tree diameter and sprouting was quite heterogeneous. However, there was a tendency for larger shoots to occur in trees of lower CAP. This can be explained by the greater vigor and metabolic activity of young individuals, allowing for greater post-pruning resilience (Kramer, 2012; Albarracín et al., 2019).

In terms of permeable soil area, the relation was significant and negative correlation $(-0.35)$ in the growth of shoots of all species. There was a trend of having larger and more sickly shoots under a soil permeability restriction condition, which may be a physiological

\section{Revista Árvore 2020;44:e4411}


Table 2 - Precision statistical indices for linear regression between the variables of shoot growth by species and climatic parameters of rainfall and temperature.

Tabela 2 -Índices estatísticos de precisão para regressão linear entre as variáveis crescimento das brotações por espécie e parâmetros climáticos de pluviosidade e temperatura.

\begin{tabular}{lcccc}
\hline Species & \multicolumn{2}{c}{ Third Quartile } & \multicolumn{2}{c}{ Mean } \\
\cline { 2 - 5 } & $\mathrm{R}^{2}$ & Probability & $\mathrm{R}^{2}$ & Probability \\
\hline Alfeneiro & $1.70 \%$ & 0.376 & $31.70 \%$ & 0.073 \\
Pata-de-Vaca & $17.50 \%$ & 0.170 & $11.20 \%$ & 0.238 \\
Castanheira & $33.30 \%$ & 0.065 & $29.00 \%$ & 0.087 \\
Escumilha-Africana & $0.00 \%$ & 0.532 & $0.00 \%$ & 0.842 \\
Espatódea & $2.50 \%$ & 0.362 & $0.00 \%$ & 0.657 \\
Fícus-Benjamim & $20.00 \%$ & 0.148 & $0.00 \%$ & 0.454 \\
Flamboyant & $0.00 \%$ & 0.978 & $28.40 \%$ & 0.090 \\
Ipê-Rosado & $38.70 \%$ & $0.049^{*}$ & $36.20 \%$ & $0.048^{*}$ \\
Jacarandá-Mimoso & $56.60 \%$ & $0.009^{*}$ & $0.004^{*}$ \\
Magnólia & $28.70 \%$ & 0.089 & $33.70 \%$ & 0.064 \\
Mangueira & $27.10 \%$ & 0.098 & $24.60 \%$ & 0.114 \\
Munguba & $8.70 \%$ & 0.269 & $15.80 \%$ & 0.187 \\
Oiti & $0.00 \%$ & 0.466 & $9.70 \%$ & 0.256 \\
Paineira & $41.10 \%$ & $0.036^{*}$ & $44.50 \%$ & $0.029^{*}$ \\
Quaresmeira & $29.60 \%$ & 0.083 & $27.40 \%$ & 0.096 \\
Sibipiruna & $41.00 \%$ & $0.038^{*}$ & $37.70 \%$ & $0.046^{*}$ \\
\hline All Species & $37.90 \%$ & $0.042^{*}$ & $32.30 \%$ & $0.050^{*}$ \\
\hline * significant at 5\% probability by the T test. & & & & \\
* significante à 5\% de probabilidade pelo teste T. & & &
\end{tabular}

response to the stress condition of trees in the urban environment (Dobbertin, 2005; Miller et al.,2015).

Regarding individuals and good sanitary conditions, individuals that presented few or no lesions in the branches or trunk had the highest incidence and development of shoots, as also described by Melo et al. (2007) and Hirons and Percival (2012).

Table 3 - Linear correlation between the variables of species shoot growth and intensity of pruning applied.

Tabela 3 - Correlação linear entre as variáveis crescimento das brotações por espécie e intensidade da poda aplicada.

\begin{tabular}{lcr}
\hline Species & Correlation & Interpretation \\
\hline Alfeneiro & 0.43 & Moderate correlation \\
Pata-de-Vaca & 0.78 & Strong correlation \\
Castanheira & -0.36 & Poor correlation \\
Escumilha-Africana & -0.36 & Poor correlation \\
Espatódea & 0.43 & Moderate correlation \\
Fícus-Benjamim & 0.30 & Poor correlation \\
Flamboyant & -0.37 & Poor correlation \\
Ipê-Rosado & 0.01 & Very Poor correlation \\
Jacarandá-Mimoso & 0.60 & Moderate correlation \\
Magnólia & -0.26 & Poor correlation \\
Mangueira & -0.71 & Strong correlation \\
Munguba & -0.70 & Strong correlation \\
Oiti & -0.03 & Very Poor correlation \\
Paineira & -0.61 & Moderate correlation \\
Quaresmeira & 0.04 & Very Poor correlation \\
Sibipiruna & -0.07 & Very Poor correlation \\
\hline All Species & -0.21 & Poor correlation \\
\hline
\end{tabular}

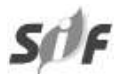

In relation to the solar incidence, the highest shoots were observed for those trees with direct solar incidence. This was a physiological response also expected by the direct relation between photosynthesis and tree development (Kirschbaum, 2011; Kramer, 2012).

\section{CONCLUSIONS}

The tree species studied present a differentiated growth response for post-pruning of shoots and, as a result, can be grouped in similarity groups by habit of development. The pruning management regime should consider the regrowth rate of each group of trees, recommending interventions between 6 and 24-month intervals.

Environmental factors differently influence the growth of species after pruning management. Climatic factors and pruning intensity were very heterogeneous between the groups. Regarding tree diameter, there was a tendency for larger shoots in younger and more vigorous individuals. For permeable soil area, it was observed that there were larger and less healthy shoots in conditions restricted soil permeability due to stress related aspects. Individuals with good sanitary conditions and direct solar incidence had higher physiological response in shoots. This fact should be studied by species on a case by case basis.

Revista Árvore 2020;44:e4411 


\section{ACKNOWLEDGEMENTS}

We would like to thank for partnership and data section as Minas Gerais Energy Company (CEMIG) the Graduate Program in Forest Sciences at the Federal University of Lavras (UFLA) and the development agency Coordination for the Improvement of Higher Education Personnel (Capes) for the scholarship.

\section{REFERENCES}

AlbarracínV, Hall AJ, Searles PS, Rousseaux MC. Responses of shoot growth, return flowering, and fruit yield to post-pruning practices and growth regulator application in olive trees. Scientia Horticulturae. 2019;254:163-171.

Blagitz M, Botosso PC, Bianchini E, Medri ME. Periodicidade do crescimento de espécies arbóreas da Floresta Estacional Semidecidual no Sul do Brasil. Scientia Forestalis. 2016;44(109):163-173.

Blum CT, Borgo M, Sampaio ACF. Espécies exóticas invasoras na arborização de vias públicas de MaringáPR. Revista da Sociedade Brasileira de Arborização Urbana. 2008;3(2):78-97.

Bobrowski R, Zamproni K, María T, Biondi D. Variability and balance of crown projection of trees planted on sidewalks of three Brazilian cities. Cerne. 2017;23(3):321-327.

Brun FGK, Longhi SJ, Brun EJ, Freitag AS, Schumacher MV. Comportamento fenológico e efeito da poda em algumas espécies empregadas na arborização do bairro Camobi-Santa Maria, RS. Revista da Sociedade Brasileira de Arborização Urbana. 2007;2(1):44-63.

Cabral PID. Arborização urbana: problemas e benefícios. Revista Especialize On-line. 2013;1(6):1-15.

Companhia Energética de Minas Gerais - CEMIG. Manual de arborização. Belo Horizonte: CEMIG/ Fundação Biodiversitas; 2011. 112 p.

Dobbertin M. Tree growth as indicator of tree vitality and of tree reaction to environmental stress: a review. European Journal of Forest Research. 2005;124(4):319333.
Ferreira RB, Leonel S, Silva MS, Souza JMA, Bolfarini AC, Modesto JH, Artigiani Filho VH. Induction of sprouting on physicochemical profile and bioactive compounds in peach cultivars by foliar applications. Idesia. 2019;37(2):51-58.

Fontoura LFM. Campo, cidade e a natureza recriada na artificialidade urbana. Boletim Gaúcho de Geografia. 2011;36(1):43-51.

Gomes I. Sistemas naturais em áreas urbanas: estudo da regional Barreiro, Belo Horizonte (MG). Caminhos de Geografia. 2005;13(14)139-150.

Gómez-Baggethun E, Barton DN. Classifying and valuing ecosystem services for urban planning. Ecological Economics. 2013;86:235-245.

Hirons AD, Percival GC. Fundamentals of tree establishment: a review. In: Johnston M, Percival G. (Eds.) Proceedings of the Urban Trees Research Conference, 'Trees, People and the Built Environment'. Forestry Commission; 2012. p. 51-62.

Jacob Neto J, Lemos JJ, Machado AL. Minimização do processo de poda em árvores utilizadas no paisagismo urbano. Semioses. 2016;10(3):21-35.

Kirschbaum MUF. Does enhanced photosynthesis enhance growth? Lessons learned from $\mathrm{CO}_{2}$ enrichment studies. Plant physiology. 2011;155(1):117-124.

Kramer P. Physiology of woody plants. Elsevier; 2012. $811 \mathrm{p}$.

Melo RR, Lira Filho JA, Rodolfo Júnior F. Diagnóstico qualitativo e quantitativo da arborização urbana no bairro Bivar Olinto, Patos, Paraíba. Revista da Sociedade Brasileira de Arborização Urbana. 2007;2(1):64-80.

Melo EFRQ, Severo BMA. Avenida Brasil (Passo Fundo, Rio Grande do Sul): diversidade da vegetação e qualidade ambiental. Revista da Sociedade Brasileira de Arborização Urbana. 2010;5(3):01-17.

Miller RW, Hauer RJ, Werner LP. Urban forestry: planning and managing urban greenspaces. $3^{\text {rd }} \mathrm{Ed}$. Waveland press; 2015. $560 \mathrm{p}$.

\section{Revista Árvore 2020;44:e4411}


Sagebiel J, Glenk K, Meyerhoff J. Spatially explicit demand for afforestation. Forest Policy and Economics. 2017;78:190-199.

Salbitano F, Borelli S, Conigliaro M, Chen Y. Guidelines on urban and peri-urban forestry. Rome: FAO; 2016. 172 p.

Taiz L, Zeiger E. Plant physiology. 4 ed. Sunderland, MA; 2006. 764 p.
Vogt J, Hauer RJ, Fischer BC. The Costs of Maintaining and Not Maintaining the Urban Forest: a review of the urban forestry and arboriculture literature. Arboriculture \& Urban Forestry. 2015;41(6):293-323.

Wang JX, Li Y, Tian WM. Physiological responses of two rubber tree clones with differential cold-tolerant potential to cold stress. Journal of Rubber Research. 2017;20(2):117-129. 